\title{
Management of Internal Quality Assurance In Character Education
}

\author{
Rakhma Agustina Sulistyowati ${ }^{1)}$, Achmad Supriyanto ${ }^{2)}$, Mustiningsih ${ }^{2)}$ \\ ${ }^{1)}$ SDIT Ibnu Hajar \\ ${ }^{2)}$ Educational Management-Universitas Negeri Malang \\ Jl. Gondorejo, Beji, Junrejo, Kota Batu. E-mail: rakhma.nuning@gmail.com
}

\begin{abstract}
This study aims at describing the internal quality assurance management in character education. This research was a qualitative research using multi-site design study. The data of this research was obtained through observation, interview, and documentation. The data analysis was performed with single site data analysis and cross-site data analysis. The findings of this study were the implementation of quality assurance of school's vision and mission and the meaning of quality assurance; The establishment of indicators of quality standards and their implementation systems; The implementation of quality standard using activity program; The evaluation of student quality standard by using observation method and self-report; The quality standard control using routine guidance for teachers, guidance for students and SOP changes; The improvement of quality standards with improvements in indicators, quality of human resources and teachers in preparation for improving quality standards.
\end{abstract}

Key Words: internal quality control, SDIT, character education

\begin{abstract}
Abstrak: Penelitian ini bertujuan untuk mendeskripsikan manajemen penjaminan mutu internal dalam pendidikan karakter. Penelitian ini merupakan penelitian kualitatif dengan menggunakan rancangan studi multi situs. Data untuk penelitian ini didapatkan melalui observasi, wawancara, dan dokumentasi. Analisis data dilakukan dengan situs tunggal data analisis dan analisi data lintas situs. Temuan dari penelitian ini adalah implementasi penjaminan mutu visi dan misi sekolah dan arti penjaminan kualitas; pembentukan indikator standar mutu dan sistem pelaksanaanya; pelaksanaan standar mutu menggunakan program aktivitas; evaluasi standar mutu siswa dengan menggunakan metode observasi dan lapor diri; pengendalian standar mutu menggunakan pembinaan rutin untuk guru, bimbingan untuk siswa dan perubahan SOP; peningkatan standar mutu dengan peningkatan indikator, kualitas sumber daya manusia dan guru dalam persiapan peningkatan standar mutu.
\end{abstract}

Kata kunci: penjaminan mutu internal, SDIT, pendidikan karakter

Character education is a system to cultivate character values to school's community. It includes knowledge, awareness or willingness and actions to apply the values. Character education is implemented as integrated and integral school system. Character development is associated with education quality which is part of services given by the school to students, teachers, parents, and society.

In the context character education, quality is measured by performance of graduates or their ability to fulfill the standard of character accomplishment as what have been stated by each education units. School character building needs an integrative effort from all school components in order to give the best services for the students. Integrated management quality approach can be seen as one of the managements in character building which can give assurance for the service users. The accomplishment of education quality is not separated from quality assurance system.

Education quality assurance is important to make the expected quality standards is clear, the program in line with its purpose, and parents' support to the school program can be stronger. Education quality assurance becomes the important factor in accomplishing better education quality. Quality assurance is associated with character education. School quality assurance gives a description of the management processes which is intended to fulfill character quality standard and can 
be the examples of other schools to evaluates and improve their character education.

Islamic Integrated Elementary School (SDIT) Al Uswah Surabaya has character quality assurance which is called special characters with Islam values as the philosophical and practice base. The special characters are (1) right prayer, (2) honesty, (3) right wudhu, (4) greeting-polite-courtesy, and (5) clean body and environment. Al Uswah's special characters are based on Islamic Integrated Elementary School Network (JSIT) and adapted with school's vision and mission. While Islamic Integrated Elementary School (SDIT) Insan Permata Malang has 12 targeted character quality assurance, they are (1) right and good prayer, (2) discipline and responsible, (3) respecting teachers and be filial to parents, (4) greeting-politecourtesy, (5) good social behavior, (6) thorough grade in 5 subjects, (7) neat and clean culture, (8) Tarteel Al-Quran reading, (9) memorize 2 Al-Quran's juz', (10) good reading habit, (11) good reading strategy, (12) good communication skill.

The character is a set of good values owned by an individual. Lickona (2013:82) explains that character consists of moral knowledge, moral feeling, and moral act. Another definition explained by Nucci and Narvaez (2014) character is a set of component skills that can be cultivated to students until a high level of ethics. Concepts of Islamic Integrated Schools's (SIT) students includes 10 detail characters named $m u$ washawat, as it is explained in Sistem Penjaminan Mutu SIT (2010:46). That ten characters become the base of Islamic Integrated Schools in formulating their quality assurance. In everyday practice, schools are given the freedom to formulate their own quality assurance based on school's vision, mission, and goal.

According to Lockwood (1997), character education is school activity intended to systematically shape students' behavior. According to Nucci (2014), the formulation of students' character is from their experience in doing it and their knowledge. That is why schools compose ethics experience which will be experienced by students in systematic schools' program.

Character education which is implemented in Islamic Integrated School (SDIT) to fulfill the standard of graduates competence is decided by Islamic Integrated Schools Network (JSIT). Standards of graduates competence are requirements of graduates competence which includes behavior, knowledge, and skill. Its scope consists of criteria of students ability which is expected to be accomplished after they graduate.
This standard becomes the base of Islamic Integrated Schools' (SIT) students quality. It includes 4 competence spheres which show 10 goals of Islamic Integrated Schools Network, they are (1) faith competence which includes clean aqeedah, right prayer; (2) personality and social competence which includes mature personality, independent, hardworking and discipline, doing things orderly and carefully, optimized use of time, be useful for others; (3) knowledge competence which includes smart, insightful and have good skill in technology, (4) physical and skill competence which includes physical strength and skill.

Management of internal quality assurance in character education is intended to create better students in accordance to schools standard. Quality assurance according to Palmer in Wijono (2000) defines quality assurance as a process of measuring quality, analyzing weaknesses and formulating activities to improve the system which is followed by another measuring quality process to find whether the improvement has been accomplished or not. Internal quality assurance system in character education is a systematic quality assurance activities by school autonomously to control and improve character education planlessly and sustainably.

This study is aimed to describe the management of internal quality assurance in character education at SDIT Al Uswah Surabaya and SDIT Insan Permata Malang. It includes (1) base of management internal quality assurance implementation, (2) process of quality standard establishment, (3) the implementation of quality standards, (4) the evaluation of quality standards, (5) the control of quality standards, (6) the improvement of quality standards.

\section{METODE}

This study uses the qualitative approach with two considerations, they are (1) management of internal quality assurance in character education becomes a solid part of school education process. With the qualitative approach, the researcher tries to reveal how management of internal quality assurance is implemented during character education at schools. The qualitative study emphasizes more on the process than the result; (2) to reveal the natural phenomenon that happens, the researcher as the main source of information and was the object place during the study.

The researcher used multi-site study, modified analytic induction design. The reason was because two sites have similarities in school basic values, refer- 
ence for character education, management of internal quality in-school character education pattern. The data were repeatedly obtained, the later obtained data were analyzed, and used to modify the temporary theories from previous data. The researcher had to be in the schools because of its role as a key instrument. The data sources for this study were the respondent who was the practitioner of management of internal quality assurance at schools. This study was conducted in SDIT Al Uswah Surabaya and SDIT Insan Permata Malang. The data were obtained through deep interview; observation of principal, school management, vice principal, curriculum staffs, student staffs, and Al-Quran teachers; nonparticipant observation; and documentation study. The data were obtained from documentation of schools profile, documentations of the result of management of quality assurance meeting, and the quality manual. The data were analyzed by using single site data analysis and cross sites data analysis. Data validity check and data interpretation in this study used credibility test, dependability, and confirmability. The credibility test used triangulation method and sources. Dependability test used audit findings method. Confirmability test used audit assurance. The researcher consulted the proposal organization, proposal development, the focus of study formulation, data collection, data analysis, and research report with advisors. The consultation was done gradually and as a whole after the report was ready to be tested.

\section{RESULTS}

The findings of first focus across sites on the base of implementation internal quality assurance in character education are (a) quality commitment of the schools' principals to build character education with good quality to create students' character based on school standards, (b) building education character system with holistic learning approach which fulfill 3 spheres (affective, cognitive, and psychomotor), (c) the implementation of school's vision and mission in character education, (d) quality assurance becomes evaluation and quality measurement tools.

The findings which focus on the establishment of quality standard on character education are (a) the implementation of quality standard establishment consists of the main team of schools' principal, schools' curriculum and student staffs, and executive team of all of the teachers, (b) the time of quality standard establishment on the end of school year, (c) mechanism for quality standard establishment, (d) the reference for the establishment are school's vision and mission, quality standard from Islamic Integrated Schools Network (JSIT), schools' support (teachers' capability, students' psychological development, schools' environment and facilities), (e) the form of establishment which are, quality assurance, indicators of quality assurance accomplishment, and the system of quality assurance implementation.

The findings which focus on the implementation of quality standard on character education are (a) teacher and administrative staffs quality standard program which are orientation for employer, routine personality training from institution, competence and AlQur'an training, (b) quality standard program for students like socialization of the Standard Operating Procedure of the internal quality assurance in character education and accomplishment of quality assurance program for students, (c) implementation of quality standard system using PDCA cycle.

The findings which focus on quality standard evaluation in character education are (a) the mechanism of quality standard evaluation through multilevel evaluation meeting, (b) the form of quality standard evaluation includes teachers, students, and procedures; the evaluations are daily, monthly, middle and the end of semester; evaluation methods are self-report, observation, presentation; the instruments are checklist, observation sheets, rating scale; (c) the result of teachers' quality evaluation is teachers' report or score of teachers' performance and students' quality evaluation result is quality or character assurance report, $\mathrm{Al}$-Quran report, and academic report. The result of evaluation on implementation procedure standard is for SOP revision. From the result of evaluation, it is found that teachers' and administrative staffs' quality has fulfilled more than $80 \%$ of teachers' and administrative staffs standard of SDIT. SDIT's students have fulfilled $80 \%$ of character quality standard.

The findings which focus on quality standard control on character education are (a) the control on teachers' and administrative staffs' quality standard is through personality and competence training; (b) the control on students' quality standard is through intensive training for students who have not met the requirement; (c) the control on standard operational procedure is through revising the implementation system and adjusting the quality assurance indicators; (d) communication and cooperation with parents.

The findings which focus on the improvement of quality standard on character education are (a) the basis of quality standard improvement is the result of 
students' evaluation and the identification of the needs in future education, (b) the mechanism of quality standard improvement is through improvement of quality assurance indicators, establishment of standard accomplishment system, and the improvement of teachers' quality.

\section{DISCUSSION}

\section{The Basis of Implementation Management Quality Assurance in Character Education}

First of all, quality commitment from the founder and principal of the schools is manifested through establishing character education system which can create good character students in accordance with school standard. The effort from schools to consistently implement character education is for fulfilling the wishes and needs of customers. Quality commitment is the indicators of the successful implementation of integrated management at schools. Quality assurance as something to encourage schools to have quality culture like values become beliefs and the principle of education stakeholders. Schools with good and healthy moral environment and also good program to teach morality will have staffs or principals and other stakeholders with high moral values (Lickona, 2013, p.455). Second, quality assurance as steering program in character education. Quality assurance is later inherited into indicators quality assurance accomplishment and program of indicators accomplishment, thus, it will decrease the errors during the character education process. The purpose of quality assurance is to avoid errors during character education at schools. Third, the system of character education with a learning approach that includes three spheres(affective, cognitive, and psychomotor). This is the implementation of Islamic Integrated Schools role as education administrator with integrated faith, knowledge, and donations aspect; cognitive, affective, and psychomotor aspect (Standard mutu JSIT, 2010). Fourth, quality assurance on character education as an effort to transfer schools' vision and mission. Schools have become an institution to shape character which can suit people's needs and wishes at future. Fifth, quality assurance on character education is used to measure and evaluate the result of quality standard implementation. Evaluation is used to know the factors that cause the failure to achieve the quality standard. The purpose of quality assurance is to help schools to score and review the implementation as well as the result of learning quality improvement.

\section{The Establishment of Quality Standard on Character Education}

First of all, the mechanism of the establishment of the quality standard is through a working meeting which begins with a review of schools' vision, mission and goal, and also strengthen the motivation to work. According to Supriyanto (2011), one of the indicators of a successful school in quality management is big motivation and settled organization. Second, the reference to quality standard establishment is Islamic integrated School's quality, school's vision and mission; School's internal capability (Wijoni, 2000) explains that in planning the quality assurance, it starts with arranging the priority quality which we want to accomplish, understanding the school limitation to fulfil all quality aspects simultaneously. The arrangement of the quality standard by using environment analysis can tell the school's strengths and weaknesses. The third is the form of indicator establishment of quality assurance accomplishment. Indicators as measurement tools for quality assurance accomplishment; quality assurance accomplishment program which is relevant to school's goal; a system of quality assurance accomplishment program implementation is needed to arrange program which can systematically shape students' behavior.

\section{The Implementation of Quality Standard on Character Education}

First, school quality assurance needs to establish quality accomplishment which has been established by arranging the steps of the implementation of quality assurance program. With the implementation procedure of good behavior which is developed into rules that should be obeyed and the presence of consequences for not obeying the rules, the implementation of the quality standard will be more planned and systematic. Second, the working program is done with PDCA cycle which also can be used as a quality control process. Quality control process includes parents role in habituating character at home (it can be in the form of home visit program and also filling and monitoring through communication books). Parents involvement in character education can mean a lot to the student's development and the school and parents cooperation in charac- 
ter education is stated by Lickona (2013, p.57) students' good attitude can vanish if the values that have been taught to them do not get support from home.

\section{The Evaluation of Quality Standard on Character Education}

First, the evaluation mechanism is a working meeting which is done in each unit. Working meeting in each unit based on the wide scope of each responsibility in order to score and review the implementation as well as the result of character education. Second, the teacher evaluation is in the form of teacher's report or PKG. The teacher's report or PKG is the report of teacher's performance and personality within a month which is done by school's principals. The teacher's report gives a chance to every teacher to know their performance and can independently reflect and evaluate their own achievement in every month.

Third, the evaluation method for students' quality is by dividing the process of evaluation into several periods, they are: daily, monthly, and semestral evaluation. The method for daily evaluation is self-report and observation. By observation, teachers can watch behavior or attitudes, response, or indicators of quality assurance accomplishment which appears. By that, the result of evaluation will be more accurate because the data are complete and the policy taken will also be context. The observation needs teachers to be active to watch students and fill the result on the observation sheet. Monthly evaluation is by the presentation, self-report, and observation. Weekly or monthly evaluation is done by counting the accumulation of quality assurance indicators that have been accomplished by students. Periodic evaluation gives an advantage. It helps teachers to control students quality earlier and usually to make sure that the students have been on the right track based on the established standard. By thus, there will be a direct follow-up if there is a deviation during the implementation of quality standards. The total evaluation of the successful of quality assurance program accomplishment and the fulfillment of quality assurance indicator is done by schools' principal and teachers at the end of school year. Third, the result of evaluation will be in the form of a report. Generally, the report is quality assurance report or character report, Al-Quran report, academic report and teacher report for teachers or PKG. The data in character report comes from the daily, weekly, and monthly evaluation that are recapitulated by teachers. The follow-up for evaluation will give three conditions. The first condition, students, teachers, and administrative staffs have met the quality standard, second students, teachers, and administrative staffs bellow or deviate the quality standard, third condition students and teachers have exceeded the quality standard that has been established by the school. The school will take a control measure to the quality standards which have not been accomplished or students and teachers quality standard which deviate the quality standards that have been set. While the improvement step will be done by the school if the quality standards have been exceeded.

\section{The Control of Quality Standards on Character Education}

First, the steps to control quality standards is a follow-up from the evaluation of the implementation. Scholl will take this step to finish the issue in students and teachers whose standard is bellow or deviate from the standards that have been set by the school. Second, school identifies the causes of why the quality standards have not been fulfilled. It is because of three factors, they are teachers and school's administrative staffs, students and the procedure are not match. Solution formulation is by using PDCA method through multilevel meeting mechanism which is conducted by the principal together with teachers. From the quality standard evaluation, the failure was caused by teachers' and school's administrative staffs' quality, school is implementing controlling steps to the teachers and school administrative staffs quality standard by improving personality training which is conducted by the institution. The cause of students' quality failure by using controlling steps to students' quality through punishment which is given to students who violated the rules which resulted in the failure of quality standard accomplishment; students are given intensive training through intensive training with accompaniment activities with homeroom teacher; the involvement of parents through oral or written communication will shape perception and trigger the same responsibility between school and parents in accomplishing students' quality standard. The causes of quality failure are the wrong procedure, by making some revisions on the standard operational procedure there will be an improvement on implementation system. 


\section{The Improvement of Quality Standard on Character Education}

First, the quality improvement is conducted by the school if the quality standards have been exceeded. Second, the quality standard can be improved if the requirement is fulfilled. The requirement is if the majority of students can meet the quality standard and also if there has been the identification of what we need in future education. The evaluation result gives authentic data for a quality standard that fulfills the requirement to improve it. Sallis (2006) states that the improvement of quality standard needs mental attitudes of quality standard implementation. One of them speaks with data. That means every decisions or policy making in the education process should be based on data analysis, not on assumption or fabrication. Third, the improvement of quality standard step through the improvement of quality assurance indicators. It is based on the theory which says the quality improvement should be in line with need and ability of internal and external users; the school also communicate with the external user (parents) before improving the quality standard. The form of communication can be through parents meeting and publication of school's latter; school formulates a system to improve quality standards. By this, the quality is gained through good design and planning, not accidentally.

\section{CONCLUSIONS}

First, the basis of internal quality assurance implementation on character education consists of quality commitment from the founder and principal; holistic learning approach which includes three spheres (affective, cognitive, psychomotor); second, the establishment of quality standard is done through working forum; third, the implementation of quality standard on character education by using teachers and students quality standard program; fourth, evaluation of quality standard implementation by using mechanism of evaluation of quality standard implementation through multilevel evaluation meeting; fifth, controlling quality stand- ard on character education by controlling teachers', administrative staffs, students quality, and controlling standard operational procedure; sixth, the improvement of quality standard on character education if of the result of majority students' evaluation have met the quality standard set by school before which is intended to identify education needs in the future. Mechanism quality standard improvement is conducted through the improvement of indicators quality assurance, the formulation of standard accomplishment system, and the improvement of teachers and school administrative staffs capability.

For schools principal (1) pay more attention toward data documentation of the implementation of quality assurance which is needed to control teachers and students quality on character education; (2) pay more attention to the mechanism of controlling teacher in doing main role and set function; (3) formulate a team internal quality assurance which responsible to supervise quality assurance in order to accomplish quality assurance on character education in every year; (4) conducting investigation on graduated students character to track students character development; (5) improve communication with parents in developing students' character.

\section{REFERENCES}

Lockwood, A.T.(1997). Character Education: Controversy and Consensus. New York: Sage.

Lickona.T. (2013). Educating For Character. Jakarta: Bumi Aksara.

Nucci, L.P \& Narvaez, D. (2014). Handbook Pendidikan Moral dan Karakter. Bandung: Nusa Media.

Sallis, E. (2002). Total Quality Management In Education. London: Kogan Page.

Supriyanto, A. F. (2011). Implementasi Total Quality Management dalam Sistem Manajemen Mutu Pembelajaran di Institusi Pendidikan. Cakrawala Pendidikan, Th. XXX, No. 1.

Wijono, D. (2000). Manajemen Mutu Pelayanan Kesehatan. Vol.1. Surabaya: Airlangga University Press. 